\title{
Soil Physical Properties and Grain Yield Influenced by Cover Crops and Crop Rotation
}

\author{
César Tiago Forte ${ }^{*}$, Amauri Nelson Beutler ${ }^{2}$, Leandro Galon ${ }^{3}$, Camile Thais Castoldi ${ }^{3}$, \\ Fábio Luís Winter ${ }^{3}$, Cinthia Maethê Holz ${ }^{3}$, Felipe Bianchessi ${ }^{3}$, Germani Concenço4, \\ Leonardo Chechi1 ${ }^{1}$, Matheus Martins Ferreira1, André Andres', Giovane Matias Burg1 \\ ${ }^{1}$ Plant Science Department, Federal University of Santa Maria, Brazil \\ ${ }^{2}$ Agronomy Department, Federal University of Pampa, Itaqui, Brazil \\ ${ }^{3}$ Agronomy Department, Federal University of Fronteira Sul, Erechim, Brazil \\ ${ }^{4}$ Agronomy Department, Embrapa Temperate Agriculture, Pelotas, Brazil \\ Email: *cesartiagoforte@hotmail.com
}

How to cite this paper: Forte, C.T., Beutler, A.N., Galon, L., Castoldi, C.T., Winter, F.L., Holz, C.M., Bianchessi, F., Concenço, G., Chechi, L., Ferreira, M.M., Andres, A. and Burg, G.M. (2018) Soil Physical Properties and Grain Yield Influenced by Cover Crops and Crop Rotation. American Journal of Plant Sciences, 9, 584-598. https://doi.org/10.4236/ajps.2018.94045

Received: January 19, 2018

Accepted: March 5, 2018

Published: March 8, 2018

Copyright $\odot 2018$ by authors and Scientific Research Publishing Inc. This work is licensed under the Creative Commons Attribution International License (CC BY 4.0).

http://creativecommons.org/licenses/by/4.0/

\begin{abstract}
The crop yield is related to several factors, among these, soil tillage, soil compaction and crop rotation. This study aimed to evaluate the winter cover crops and crop rotation influence on soil physical properties and grain yield of dry beans, maize and soybean for two growing seasons. Three experiments were conducted, corresponding to dry beans, maize and soybean crops. It was used the randomized block design with three treatments and four replications consisted by $3 \times 10 \mathrm{~m}$ plots. The treatments were: two cover crops systems and crop rotation in no-till, and the control, consisting of winter fallow and conventional tillage. The cover crop dry matter, soil physical properties and grain yield for dry beans, maize and soybean in the two growing seasons were evaluated. Crop rotation systems and cover crops showed a trend to increase maize and soybean yields. Crop rotation in no-till increases soil compaction in the superficial layer compared to conventional tillage, but does not reduce the dry beans, maize and soybean yields.
\end{abstract}

\section{Keywords}

No-Till, Tillage, Dry Matter, Intercropped, Bulk Density, Soil Compaction

\section{Introduction}

Brazil is the world's largest soybean exporter with 114 million tons produced, followed by the United States [1]. In the Rio Grande do Sul state, more than $80 \%$ of the agricultural area is grown under no-tillage system (no-till), with emphasis on upland crops such as soybean and maize, due to the great and ease no-till 
adaptation and management.

The no-till conservation system area increases annually comparing to conventional soil preparation system (tillage), because tillage, generally degrades the soil, the environment and needs to be done annually with a high operational cost, since soil decompression beneficial effects remain for less than a year in this system [2] [3]. However, in no-till, soil compaction occurs by machine traffic on soil surface, which is a factor that frequently reduces the crop yield such as soybean [4] and dry beans [5], mainly under inadequate soil management conditions such as traffic under high soil moisture conditions, no crop rotation and insufficient surface straw.

Excessive soil compaction also alters the seedlings germination and emergence, deforms the root system, decreases nutrient mobility, alters nitrogen cycle, carbon cycle and soil biological activity [6], resulting in crop growth and grain yield reduction [4] [5] [7]. In the soybean crop, Siczek and Lipiec [8] found that compaction reduced nodulation and nitrogen fixation; however, the straw mulch on the soil surface mitigated the compaction negative impact. The compaction changes soil structure and occurs more intensely in the $0-17 \mathrm{~cm}$ deep layer in the no-till and after five years, the reconsolidation occurs, reducing soil compaction and bulk density; the soil structure stabilizes and reaches a dynamic equilibrium in the soil [9]. The soil contraction and expansion through wetting and drying cycles reversed most of the compaction that machine traffic causes in an Oxisol, analyzed by bulk density [10].

Low soil compaction indicates physical quality, essential for the proper growth, roots distribution in the soil profile and water, nutrients and oxygen absorption by roots to allow full plant growth and productivity [6].

Crop rotation, and cover crops (mulch on the soil surface) are two of the three essential pillars for no-till functionality and sustainability, along with the no soil disturbance. In the no-till surface straw is desirable as it reduces soil water evaporation by keeping the moisture and lessening the compaction negative effects on root growth and crop yield. This is because soil resistance to root penetration is inversely related to the water content [11] [12] [13] and in higher water content conditions, the compaction effect on crop yield reduction is mitigated [5] [6].

In this way, this study aimed to evaluate winter cover crops and crop rotation effect on soil physical properties and grain yield of dry beans, maize and soybean for two growing seasons.

\section{Material and Methods}

The experiment was conducted in 2013/14 and 2014/15 growing seasons, at $27^{\circ} 44^{\prime} \mathrm{S}$ and $52^{\circ} 26^{\prime} \mathrm{W}$ coordinates, $680 \mathrm{~m}$ of altitude and Cfa climate (temperate moist with hot summer) according to the Köppen-Geiger classification [14]. The rainfall is shown in Figure 1. The soil was classified as Typic Dystrudepts [15] and presented, prior to the experiment installation: $\mathrm{pH}$ in water: 5.7; OM: $3 \%$; $\mathrm{P}$ : 


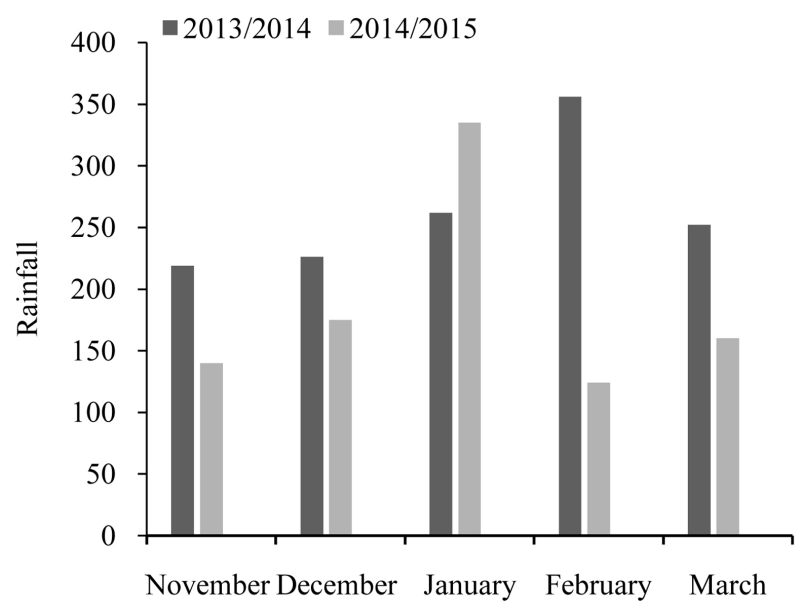

Figure 1. Rainfall, at the experimental area, in the 2013/14 and 2014/15 growing seasons.

3.7; K: 120.0 mg/L; Ca: 18.3; Mg: 6.5; H + Al: 4.9; Al: 0; Effective CEC: 25.1; and $\mathrm{CEC}_{\mathrm{pH}}: 30.0 \mathrm{cmol}_{\mathrm{c}} / \mathrm{kg}$; base saturation: $84 \%$; and clay: $30 \%$.

Three experiments were conducted, corresponding to dry beans, maize and soybean crops. The experimental design was a randomized block design, with three treatments and four replications consisting of $3 \times 10 \mathrm{~m}$ plots. The three treatments were: two cover crops systems and crop rotation under no-tillage system (no-till) and conventional winter tillage (control) (Figure 2). For the soil physical properties evaluation, a randomized block design was used, with subdivided plots, the plots being the management systems and subplots the layers of 0 5, $5-10$ and $15-20 \mathrm{~cm}$ depth.

Before the experiment, the area was in a no-till system for 10 years and, in the last two years, consecutive soybean grown in summer and cattle grazing in winter, with predominant vegetation composed of ryegrass (Lolium multiflorum). The cover crops were sown in May 2013 and 2014. The seed densities were: black oats (Avena strigosa Schreb) 130 seeds/m, forage turnip (Raphanus sativus L.) $100 \mathrm{seeds} / \mathrm{m}^{2}$, and vetch (Vica sativa) $170 \mathrm{seeds} / \mathrm{m}^{2}$; and intercropped crops: $90+50$ seeds $/ \mathrm{m}^{2}$ of black oats + vetch; $90+30$ seeds $/ \mathrm{m}^{2}$ of black oats + forage turnip; and $170+35$ seeds $/ \mathrm{m}^{2}$ of vetch + forage turnip. The sowing was done with a seed drill with $0.17 \mathrm{~m}$ between rows and $200 \mathrm{~kg} / \mathrm{ha}$ of 08-24-12 NPK formula fertilizer plus $45 \mathrm{~kg} / \mathrm{ha}$ cover nitrogen fertilizer. Fertilization was also performed in the control treatment.

The cover crops control management was performed with glyphosate herbicide at $1.08 \mathrm{~kg} \cdot \mathrm{ha}^{-1}$ dose, and sethoxydim herbicide at $0.22 \mathrm{~kg} / \mathrm{ha}, 50$ and 20 days before sowing, in the 2013/14 and 2014/15, respectively. The cover crops growth period was of 140 days, from sowing to burndown, in both years.

The summer crops were sown on November 24 and 15 for 2013 and 2014, respectively. Seedling density were 30 plants $/ \mathrm{m}^{2}$ for soybean (Glycine max) (BMX Ativa), 21 plants $/ \mathrm{m}^{2}$ for dry beans (Phaseolus vulgaris L.) (BRS Campeiro) and 6 plants $/ \mathrm{m}^{2}$ for maize (Zea mays L.) (AG 8041 PRO hybrid in 2013 and SX 7331 


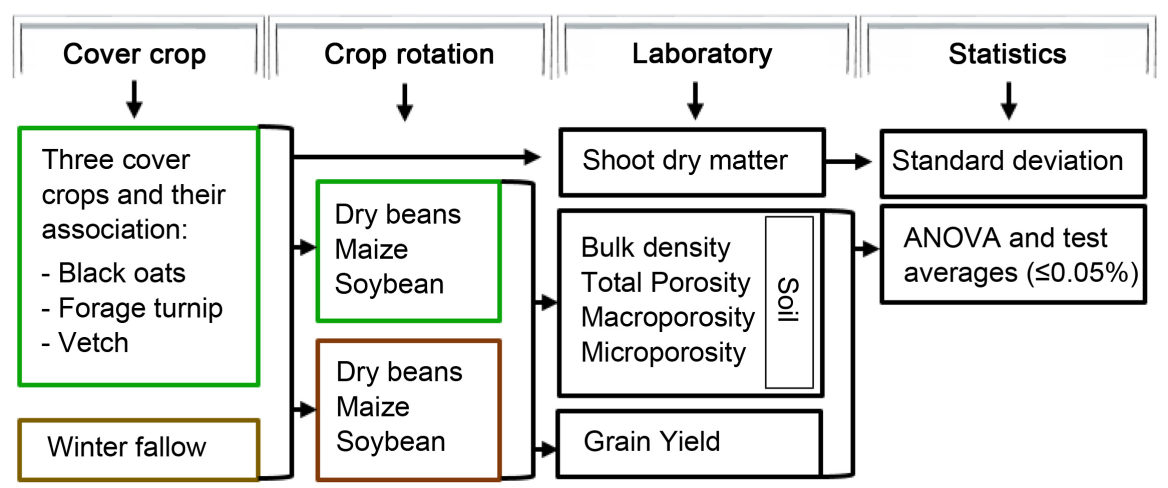

Figure 2. Methodology flow diagram showing the cover crops (no-tillage-green) and winter fallow (tillage-brown), crop rotation, laboratory analysis and statistics details.

VIP hybrid in 2014), at $0.47 \mathrm{~m}$ between rows. The base fertilization was 350 $\mathrm{kg} / \mathrm{ha}$ of $05-30-15$ NPK formula, for the three crops during the two growing seasons.

The soil physical properties were analyzed in April 2014 and 2015, after summer crops harvest, according to Claessen [16] methodology. Undisturbed soil samples $(3 \mathrm{~cm}$ high and $5 \mathrm{~cm}$ in diameter) were collected, using a soil core sampler, to evaluate the soil bulk density (BD), total porosity $(\mathrm{Pt})$, macro and microporosity in the layers of $0-5,5-10$ and $15-20 \mathrm{~cm}$ depth.

The cover crops dry matter was evaluated in a $0.25 \mathrm{~m}^{2}$ area. The dry beans, maize and soybean grain yield was evaluated in a $3 \mathrm{~m}^{2}$ area and the grain water content adjust to $13 \%$. The data were submitted to analysis of variance by the $\mathrm{F}$ test, and when significant, the means were compared by the Tukey test ( $\mathrm{p} \leq$ 0.05). In Figure 2 it is explained, in a sequential way, the procedures performed in the two years study.

\section{Results and Discussion}

The cover crops shoot dry matter showed variation according to the species and growing season, as demonstrated in Figures 3-5. In the two growing seasons the cover crops that most responded in relation to the dry matter production was the vetch, associated or not with black oats and turnip forage. It should be noted that both crop association and isolated crop species may become an alternative to increase dry matter production in comparison to fallow winter, except for turnip forage (Figure 3(a), Figure 4(a) and Figure 4(b)). Even low cover crops levels contribute to the water runoff, erosion and soil loss reduction, as well as to decrease sediment movement for cover crop levels greater than $47 \%$ [17].

In general, the turnip forage was the cover crop that presented the lowest dry matter yield, being lower in the first two seasons, even when compared to winter fallow (Figure 3(a) and Figure 5(b)).

There were changes in soil physical properties and some interactions between soil management systems and soil layers in the 2013/14 season (Table 1) and in the 2014/2015 season there were no interactions (Table 2). 


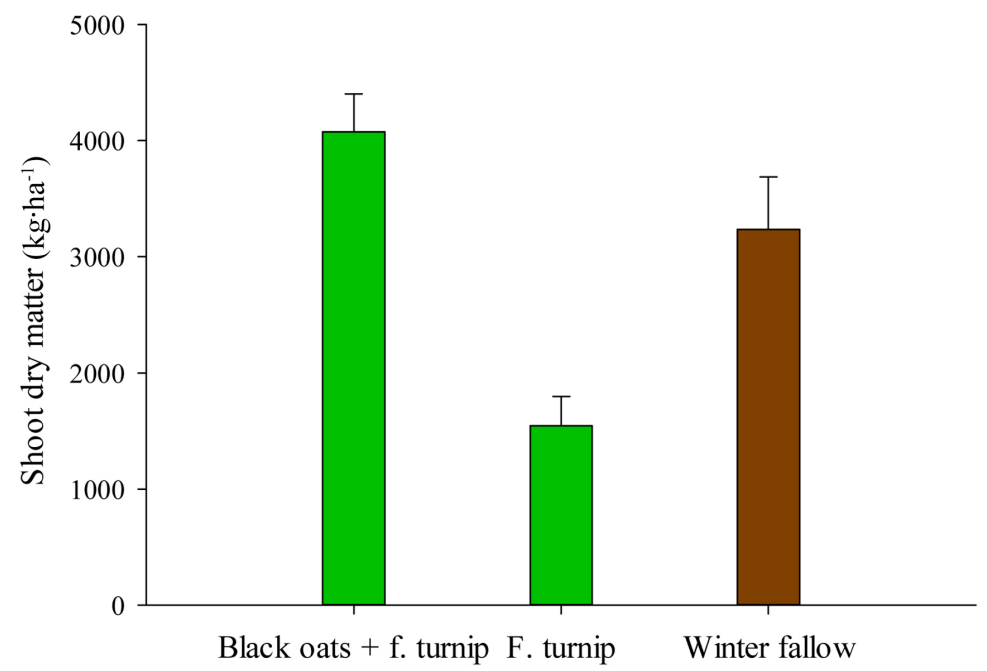

(a)

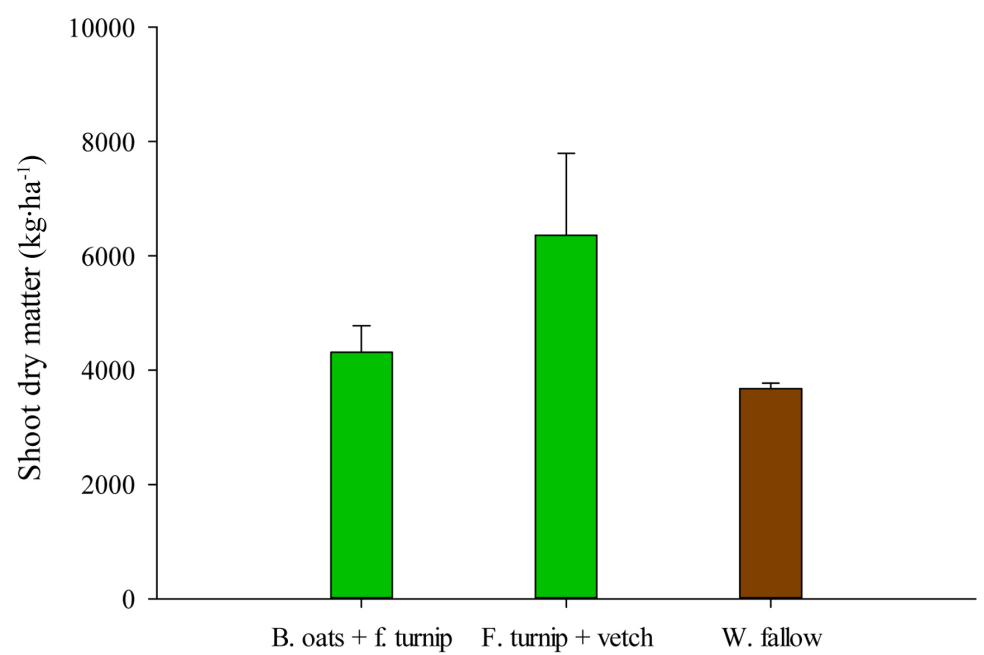

(b)

Figure 3. Cover crop shoot dry matter sown before dry beans (2013/14 season (a) and 2014/15 season (b)) summer crops. Cover crops treatments were applied a no-till management. In the winter fallow system was applied a conventional tillage before dry beans, soybean and maize sown. Vertical bars represent the standard deviation.

No-till systems with cover crops and dry beans-maize rotation presented higher soil compaction, evaluated by higher soil density and lower macroporosity, in the $0-5$ and $5-10 \mathrm{~cm}$ layers, compared to the tillage system (control) (2013/14 season-Table 1). This occurred due to the plowing and harrowing in the tillage system before summer crop sowing, which decompressed the soil in the superficial layer.

Also, in the tillage was verified that in the $15-20 \mathrm{~cm}$ layer, compaction was bigger, in relation to the upper layers, and did not differ between systems, indicating that the soil decompression by the conventional tillage occurred in layers above to $15 \mathrm{~cm}$ depth and was maintained during the summer crop cycle (Table $1)$. 


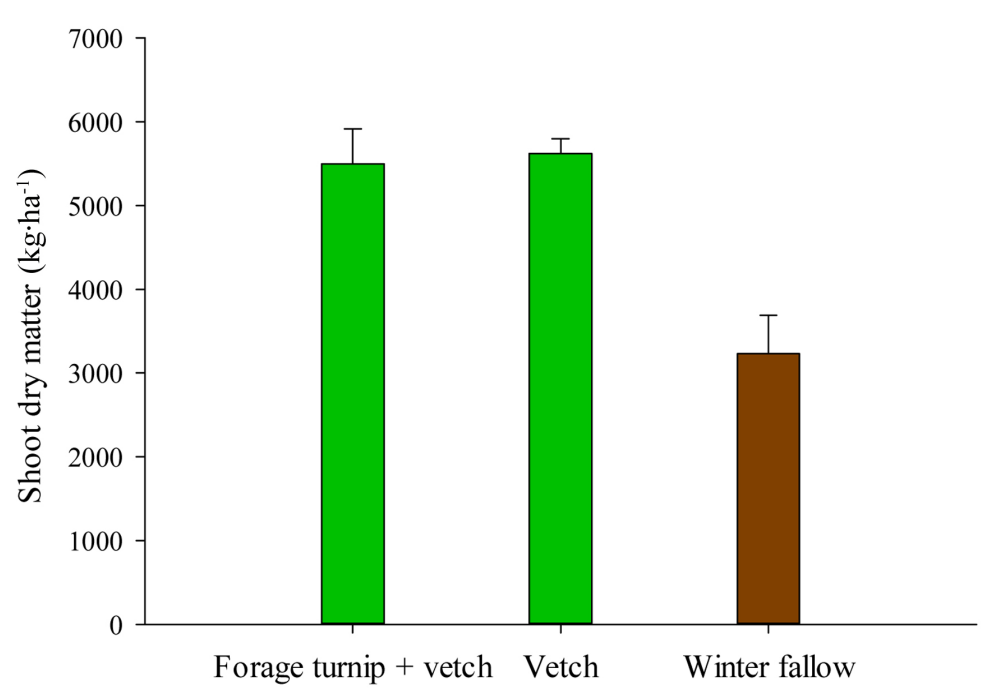

(a)

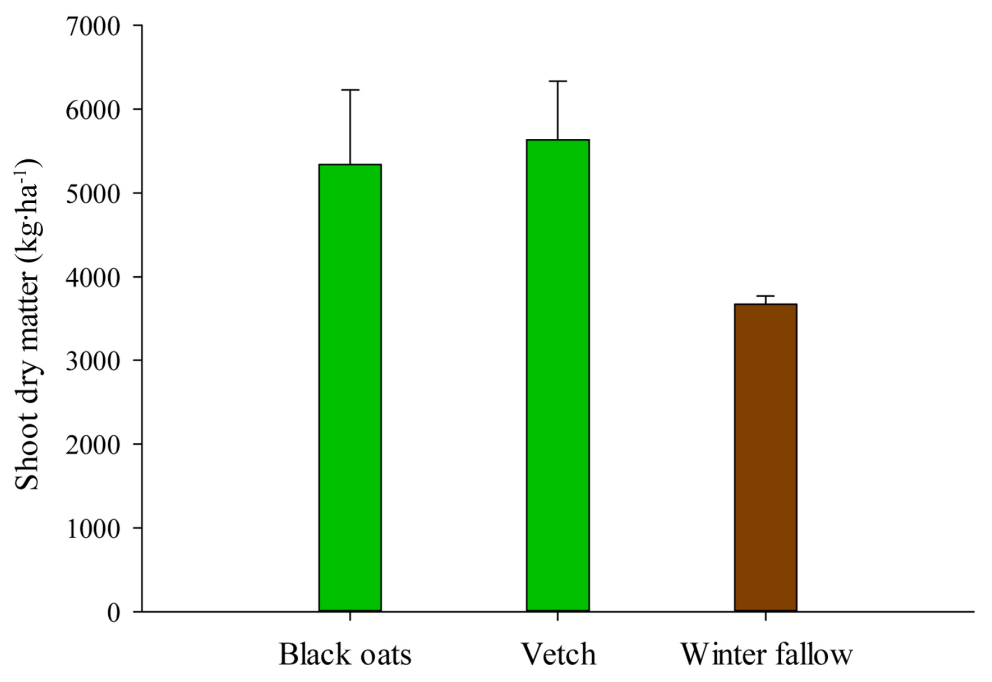

(b)

Figure 4. Cover crop shoot dry matter sown before drymaize (2013/14 season (a) and 2014/15 season (b)) summer crops. Cover crops treatments were applied a no-till management. In the winter fallow system was applied a conventional tillage before dry beans, soybean and maize sown. Vertical bars represent the standard deviation.

Smaller bulk density values and higher porosity in conventional tillage, resulting from soil disturbance in the surface layer, were observed in several studies [5] [18] [19]. However, lower compaction did not result in higher dry beans grain yield (2013/14 season Figure 6(a) and 2014/15 season Figure 6(b)), it was as also verified by Collares et al. [20] and Gubiani et al. [5] .

Although there was no difference in the soil physical properties in the no-till systems and lower compaction in the tillage system, dry beans least grain yield was obtained only when grown after forage turnip, in comparison to the black oats + forage turnip and tillage after fallow (2013/14 season Figure 6(a)). This was probably due to the high incidence of white mold (Sclerotinia sclerotiorum) 


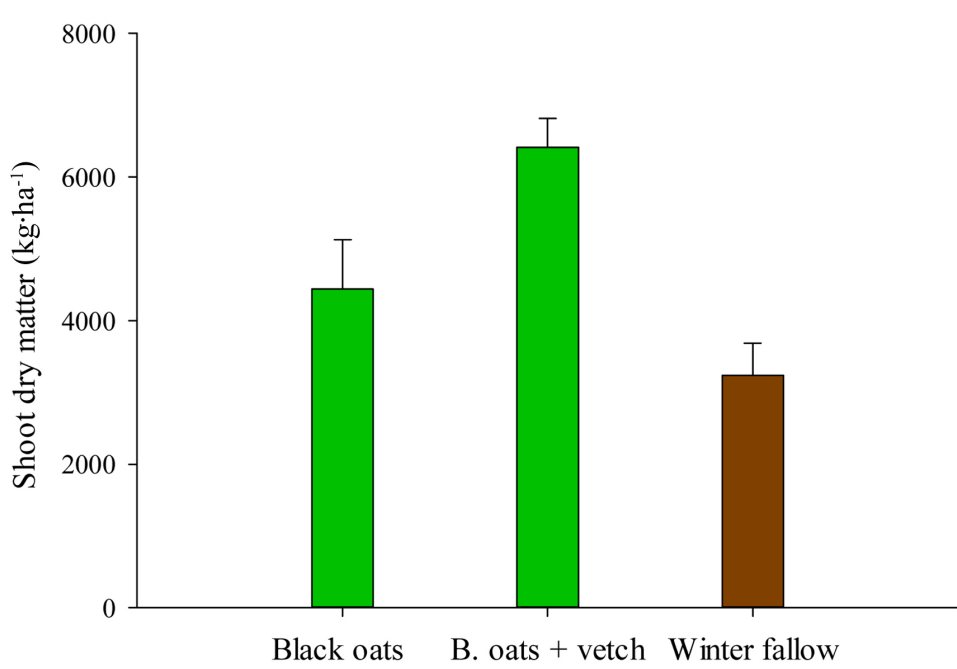

(a)

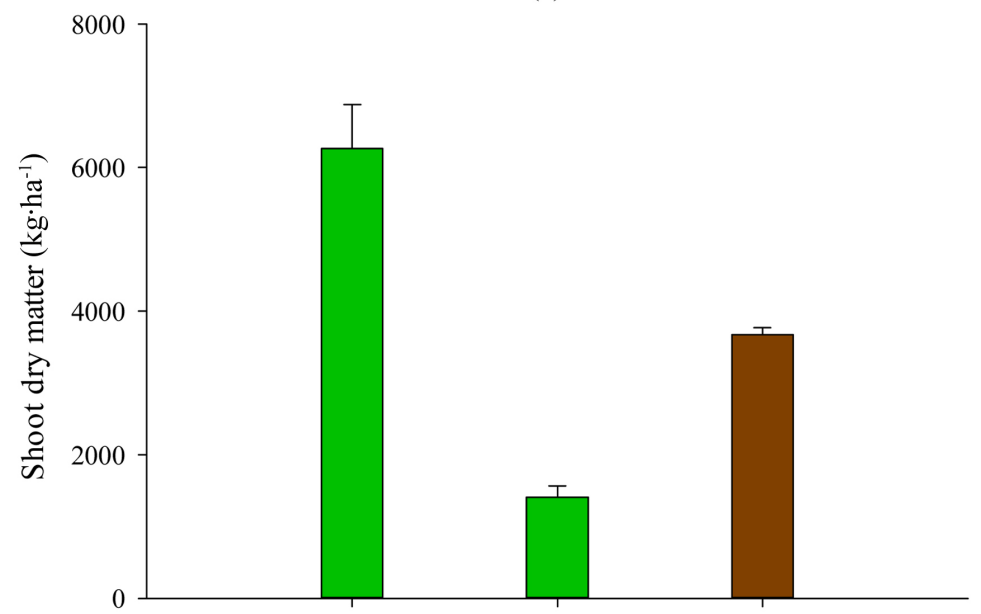

B. oats + vetch Forage turnip Winter fallow

(b)

Figure 5. Cover crop shoot dry matter sown before dry soybean (2013/14 season (a) and 2014/15 season (b)) summer crops. Cover crops treatments were applied a no-till management. In the winter fallow system was applied a conventional tillage before dry beans, soybean and maize sown. Vertical bars represent the standard deviation.

in dry beans, because forage turnip is a disease hosts [21]. White mold high incidence occurred due to the high rainfall (Figure 1) and humidity, which favored the disease development in the dry beans after forage turnip, even when the desiccation was done 50 days before the sowing. This disease is more harmful to dry beans under high humidity conditions and irrigated crops. In the forage turnip and black oats ( $25 \%$ forage turnip $+75 \%$ black oats), the disease was less intense due to the lower amount of forage turnip and black oats not to be a disease host, resulting in dry beans yield equal to obtained in winter fallow (2013/14 season-Figure 6(a)).

Dry beans grain yield in no-till with black oats + forage turnip cover crop did not differ from tillage after fallow, with lower soil compaction. This is due to the 


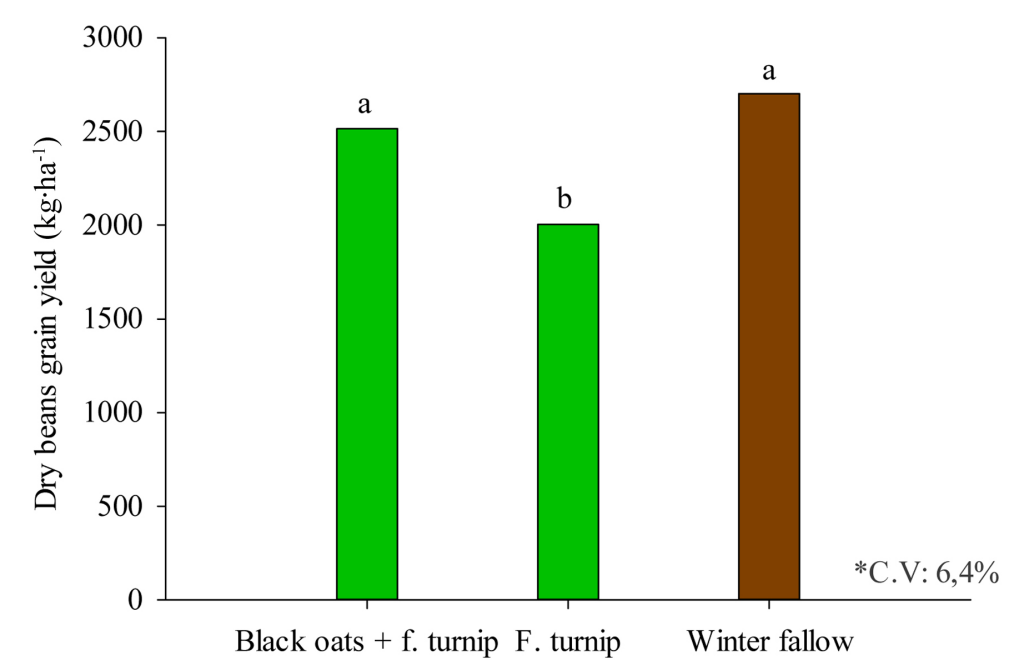

(a)

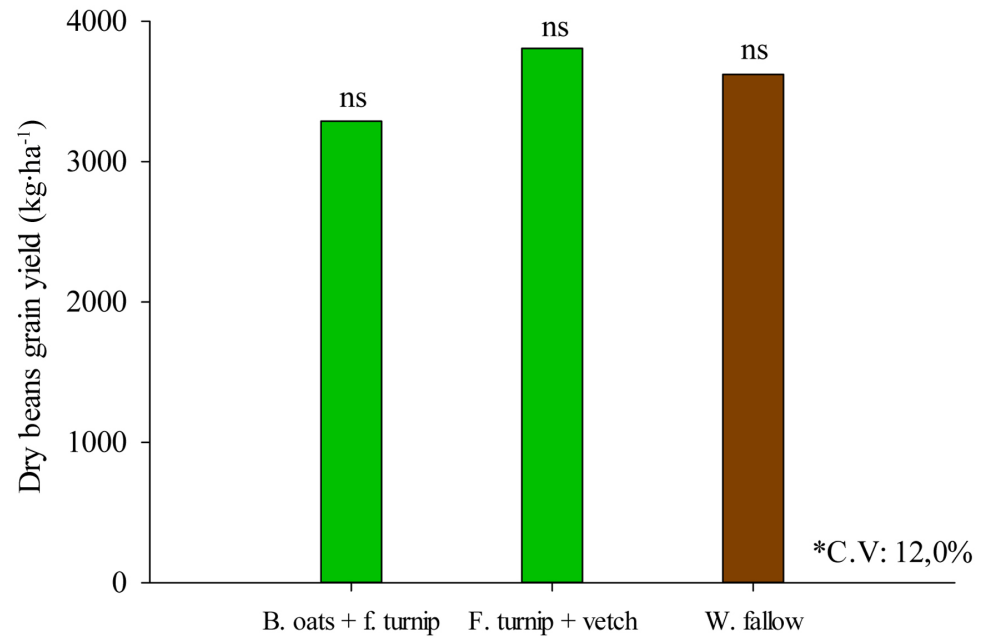

(b)

Figure 6. Grain yield of dry beans (BRS Campeiro 2013/14 season (a) and 2014/15 season (b)) to soil management practices, crop rotation and cover crops. ${ }^{\star}$ Coefficient of variation.

low values of bulk density, lower than $1.6 \mathrm{mg} / \mathrm{m}^{3}$, a value from which the crop yield decreases (2013/14 season Table 1 and Figure 6(a)), according to Reichert et al. [22], for $30 \%$ clay soils, as determined in the study. This indicates a low soil degree of compaction, even in the no-till with the highest bulk density values. Similar results were obtained by Gubiani et al. [5], in which dry beans grain yield did not differ between no-till and no-till with soil scarification, but was lower in no-till with additional compaction by four-pass tractor traffic, allowing to infer that a little compaction in no-till does not reduce dry beans grain yields.

The higher bulk density values in no-till, compared to tillage, but lower than the values from which there is crop yield reduction can also occur because the no-till is stabilized after 13 years, in which there is structure reconsolidation and bulk density reduction [9].

Between the two no-till systems, cover crops and summer crops rotation, no 
Table 1. Soil physical properties, crop rotation and cover crops, for dry beans, maize and soybean, in the 2013/14 growing season.

\begin{tabular}{|c|c|c|c|c|c|}
\hline Cover crops & $\begin{array}{c}\text { Depth } \\
\text { layer }\end{array}$ & 3ulk density & Total porosity & Microporosity & Macroporosity \\
\hline & $(\mathrm{cm})$ & $\left(\mathrm{mg} / \mathrm{m}^{3}\right)$ & ---------- & $\left(\mathrm{cm}^{3} / \mathrm{cm}^{3}\right)$ & --------------- \\
\hline \multicolumn{6}{|c|}{ Dry beans } \\
\hline \multirow{3}{*}{$\begin{array}{l}\text { Black oats + Forage } \\
\text { turnip }\end{array}$} & $0-5$ & $1.39 \mathrm{Aa}^{*}$ & $0.57 \mathrm{Ab}$ & $0.50 \mathrm{Aa}$ & $0.07 \mathrm{Bb}$ \\
\hline & $5-10$ & $1.39 \mathrm{Aa}$ & $0.58 \mathrm{Aab}$ & $0.47 \mathrm{Aa}$ & $0.12 \mathrm{Ab}$ \\
\hline & $15-20$ & $1.41 \mathrm{Aa}$ & $0.58 \mathrm{Aa}$ & $0.48 \mathrm{Aa}$ & $0.10 \mathrm{ABa}$ \\
\hline \multirow[t]{3}{*}{ Forage Turnip } & $0-5$ & $1.38 \mathrm{Aa}$ & $0.55 \mathrm{Ab}$ & $0.44 \mathrm{Bb}$ & $0.11 \mathrm{Ab}$ \\
\hline & $5-10$ & $1.41 \mathrm{Aa}$ & $0.58 \mathrm{Ab}$ & $0.46 \mathrm{ABa}$ & $0.11 \mathrm{Ab}$ \\
\hline & $15-20$ & $1.38 \mathrm{Aa}$ & $0.58 \mathrm{Aa}$ & $0.49 \mathrm{Aa}$ & $0.09 \mathrm{Aa}$ \\
\hline \multirow[t]{3}{*}{ Winter fallow } & $0-5$ & $1.13 \mathrm{Bb}$ & $0.65 \mathrm{Aa}$ & $0.38 \mathrm{Bc}$ & $0.27 \mathrm{Aa}$ \\
\hline & $5-10$ & $1.15 \mathrm{Bb}$ & $0.62 \mathrm{Aa}$ & $0.42 \mathrm{ABb}$ & $0.20 \mathrm{Ba}$ \\
\hline & $15-20$ & $1.37 \mathrm{Aa}$ & $0.55 \mathrm{Ba}$ & $0.45 \mathrm{Ba}$ & $0.10 \mathrm{Ca}$ \\
\hline \multicolumn{6}{|c|}{ Maize } \\
\hline Vetch + & $0-5$ & $1.40 \mathrm{Aa}$ & $0.53 \mathrm{Ab}$ & - & $0.10 \mathrm{Ab}$ \\
\hline \multirow[t]{2}{*}{ Forage turnip } & $5-10$ & $1.43 \mathrm{Aa}$ & $0.57 \mathrm{Aa}$ & - & $0.11 \mathrm{Ab}$ \\
\hline & $15-20$ & $1.42 \mathrm{Aa}$ & $0.58 \mathrm{Aa}$ & - & $0.09 \mathrm{Aa}$ \\
\hline \multirow[t]{3}{*}{ Vetch } & $0-5$ & $1.30 \mathrm{Aa}$ & $0.59 \mathrm{Aab}$ & - & $0.13 \mathrm{Ab}$ \\
\hline & $5-10$ & $1.43 \mathrm{Aa}$ & $0.57 \mathrm{Aa}$ & - & $0.10 \mathrm{Ab}$ \\
\hline & $15-20$ & $1.39 \mathrm{Aa}$ & $0.58 \mathrm{Aa}$ & - & $0.11 \mathrm{Aa}$ \\
\hline \multirow[t]{3}{*}{ Winter fallow ${ }^{*}$} & $0-5$ & $1.04 \mathrm{Cb}$ & $0.65 \mathrm{Aa}$ & - & $0.28 \mathrm{Aa}$ \\
\hline & $5-10$ & $1.20 \mathrm{Bb}$ & $0.60 \mathrm{Aa}$ & - & $0.17 \mathrm{Ba}$ \\
\hline & $15-20$ & $1.48 \mathrm{Aa}$ & $0.53 \mathrm{Ba}$ & - & $0.07 \mathrm{Ca}$ \\
\hline \multicolumn{6}{|c|}{ Maize } \\
\hline $\begin{array}{l}\text { Black oats + Forage } \\
\text { turnip }\end{array}$ & - & - & - & $0.46 \mathrm{a}$ & - \\
\hline Vetch & - & - & - & $0.47 \mathrm{a}$ & - \\
\hline Winter fallow & - & - & - & $0.42 \mathrm{a}$ & - \\
\hline- & $0-5$ & - & - & $0.42 \mathrm{~B}$ & - \\
\hline- & $5-10$ & - & - & $0.46 \mathrm{AB}$ & - \\
\hline- & $15-20$ & - & - & $0.47 \mathrm{~A}$ & - \\
\hline \multicolumn{6}{|c|}{ Soybean } \\
\hline Black oats & - & $1.36 \mathrm{a}$ & $0.55 \mathrm{a}$ & $0.47 \mathrm{ab}$ & $0.07 \mathrm{~b}$ \\
\hline Vetch + black oats & - & $1.43 \mathrm{a}$ & $0.57 \mathrm{a}$ & $0.49 \mathrm{a}$ & $0.09 \mathrm{ab}$ \\
\hline Winter fallow & - & $1.34 \mathrm{a}$ & $0.57 \mathrm{a}$ & $0.42 \mathrm{~b}$ & $0.15 \mathrm{a}$ \\
\hline- & $0-5$ & $1.31 \mathrm{~B}$ & $0.60 \mathrm{~A}$ & $0.46 \mathrm{~A}$ & $0.14 \mathrm{~A}$ \\
\hline- & $5-10$ & $1.39 \mathrm{~A}$ & $0.55 \mathrm{~B}$ & $0.47 \mathrm{~A}$ & $0.09 \mathrm{~B}$ \\
\hline- & $15-20$ & $1.43 \mathrm{~A}$ & $0.54 \mathrm{~B}$ & $0.45 \mathrm{~A}$ & $0.08 \mathrm{~B}$ \\
\hline
\end{tabular}

${ }^{*}$ Means followed by the same capital letter for the same cover crop system (between soil layers) and lowercase letters between cover crop systems (same soil layer) do not differ by the Tukey test at $5 \%$ for dry beans, maize and soybeans. For dry beans and maize, the results with interaction are presented and for maize and soybean the values where there was no interaction between soil management system $\times$ soil layer. 
Table 2. Soil physical properties, crop rotation and cover crops, for dry beans, maize and soybean, in the 2014/15 growing season.

\begin{tabular}{|c|c|c|c|c|}
\hline Cover crops/ & Bulk density & Total Porosity & Microporosity & Macroporosity \\
\hline Soil depth layers & $\left(\mathrm{mg} / \mathrm{m}^{3}\right)$ & \multicolumn{3}{|c|}{ - $\left(\mathrm{cm}^{3} / \mathrm{cm}^{3}\right)$-- } \\
\hline \multicolumn{5}{|c|}{ Dry beans } \\
\hline Vetch + forage turnip & $1.42 \mathrm{~A}$ & $0.54 \mathrm{~B}$ & $0.44 \mathrm{~A}$ & $0.10 \mathrm{~B}$ \\
\hline $\begin{array}{c}\text { Black oats }+ \text { forage } \\
\text { turnnip }\end{array}$ & $1.34 \mathrm{~A}$ & $0.56 \mathrm{~B}$ & $0.44 \mathrm{~A}$ & $0.12 \mathrm{~B}$ \\
\hline Winter fallow & $1.19 \mathrm{~B}$ & $0.62 \mathrm{~A}$ & $0.38 \mathrm{~B}$ & $0.24 \mathrm{~A}$ \\
\hline $0-5$ & $1.21 \mathrm{~b}$ & $0.61 \mathrm{a}$ & $0.40 \mathrm{~b}$ & $0.21 \mathrm{a}$ \\
\hline $5-10$ & $1.34 \mathrm{a}$ & $0.56 \mathrm{~b}$ & $0.42 \mathrm{ab}$ & $0.14 \mathrm{~b}$ \\
\hline $15-20$ & $1.40 \mathrm{a}$ & $0.55 \mathrm{~b}$ & $0.45 \mathrm{a}$ & $0.11 \mathrm{~b}$ \\
\hline \multicolumn{5}{|c|}{ Maize } \\
\hline Black oats & $1.34 \mathrm{~A}$ & $0.58 \mathrm{~A}$ & $0.44 \mathrm{~A}$ & $0.13 \mathrm{~B}$ \\
\hline Vetch & $1.35 \mathrm{~A}$ & $0.58 \mathrm{~A}$ & $0.43 \mathrm{~A}$ & $0.15 \mathrm{~B}$ \\
\hline Fallow & $1.21 \mathrm{~B}$ & $0.60 \mathrm{~A}$ & $0.39 \mathrm{~B}$ & $0.21 \mathrm{~A}$ \\
\hline $0-5$ & $1.23 \mathrm{~b}$ & $0.60 \mathrm{a}$ & $0.41 \mathrm{a}$ & $0.19 \mathrm{a}$ \\
\hline $5-10$ & $1.30 \mathrm{ab}$ & $0.58 \mathrm{a}$ & $0.42 \mathrm{a}$ & $0.17 \mathrm{a}$ \\
\hline $15-20$ & $1.38 \mathrm{a}$ & $0.57 \mathrm{a}$ & $0.43 \mathrm{a}$ & $0.14 \mathrm{a}$ \\
\hline \multicolumn{5}{|c|}{ Soybeans } \\
\hline Forage turnip & $1.36 \mathrm{~A}$ & $0.59 \mathrm{~A}$ & $0.46 \mathrm{~A}$ & $0.12 \mathrm{~A}$ \\
\hline Vetch + black oats & $1.41 \mathrm{~A}$ & $0.54 \mathrm{~A}$ & $0.44 \mathrm{~A}$ & $0.10 \mathrm{~A}$ \\
\hline Winter fallow & $1.33 \mathrm{~A}$ & $0.59 \mathrm{~A}$ & $0.41 \mathrm{~B}$ & $0.17 \mathrm{~A}$ \\
\hline $0-5$ & $1.28 \mathrm{~b}$ & $0.60 \mathrm{a}$ & $0.43 \mathrm{~b}$ & $0.17 \mathrm{a}$ \\
\hline $5-10$ & $1.39 \mathrm{a}$ & $0.58 \mathrm{ab}$ & $0.44 \mathrm{ab}$ & $0.14 \mathrm{a}$ \\
\hline $15-20$ & $1.42 \mathrm{a}$ & $0.54 \mathrm{~b}$ & $0.45 \mathrm{a}$ & $0.09 \mathrm{~b}$ \\
\hline
\end{tabular}

Means followed by the same capital letter for cover plant systems and lower-case letters for soil layers do not differ by the Tukey test at $5 \%$ for dry beans, maize and soybean. There was no interaction between cover crops and soil layers.

differences were verified in the soil physical properties, indicating that the different winter cover crops and summer crops did not change the soil degree of compaction according to different species dry matter amount, root system and different organic materials added by the plants. Balbinot Junior et al. [23], also did not observe changes in the soil physical properties after cover crops and dry beans, maize and soybean in the summer, in no-till system. Martins and Rosa Junior [24] also did not verify changes in bulk density and total porosity, after maize harvest, with the use of forage turnip, black oats and vetch isolated or intercropped as winter cover crops in no-till system.

Maize and no-till after vetch yielded more grain compared to tillage in two years (2013/14 season and 2014/15 season), after winter fallow that presented lower soil compaction (Figure 7(a), Figure 7(b), Table 1 and Table 2). It can be explained because vetch fixes nitrogen and after its decomposition releases high 

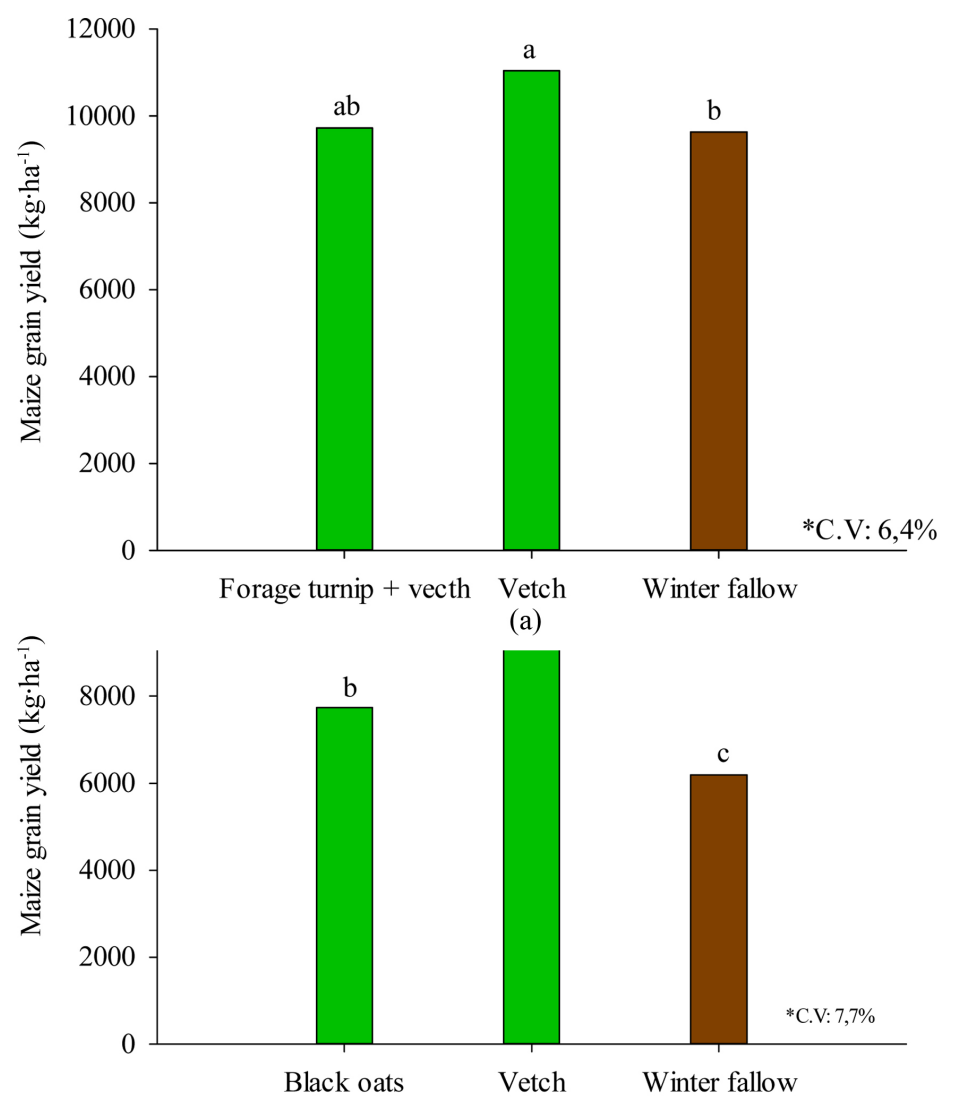

(b)

Figure 7. Grain yield of dry maize (AG 8041 PRO hybrid 2013/14 season (a) and SX 7331 VIP hybrid 2014/15 season (b)), to soil management practices, crop rotation and cover crops. ${ }^{\star}$ Coefficient of variation.

nitrogen amounts in the soil, which is used by the subsequent maize crop, which is a highly demanding and N-responsive grass [25]. In the no-till, with vetch, the highest maize yield occurred also due to the well distributed rainfall during the crop cycle, which softens the soil compaction effect in the no-till (Figure 1, Figure 7(a) and Figure 7(b)) and, by the soil root penetration resistance and soil moisture content inverse relation, in the way that soil moisture content increases, soil root penetration resistance decreases [5] [12]. However, in no-till, low bulk density values occurred bellow to the limiting values [22], indicating that the soil was not excessively compacted. However, the no-till with the vetch + forage turnip intercropped presented the same maize grain yield compared to the winter fallow tillage, possibly due to the smaller vetch dry matter amount, which contains more $\mathrm{N}$ in relation to the forage turnip, considering that the soil degree of compaction does not differed between the two no-till systems (Table 1 and Figure $7(a))$ in the first year during the experimental period (2013/14 growing season).

In this context, the vetch beneficial effect was higher than the negative soil compaction effect in the no-till using vetch as cover crop, resulting in higher maize grain yield in this system compared to tillage. Also, maize grain yield in 
no-till after vetch + forage turnip intercropped was the same as that obtained in tillage, indicating that the management system (soil preparation) has little influence on grain yield (2013/14 season Figure 7(a)). Similar results were obtained by Marcolan and Anghinoni [18], who did not verify difference in maize grain yield in tillage compared to 12 -year no-till, after black oats cover crop in winter, even with no-till presenting higher soil bulk density, lower total porosity and macroporosity. Fidalski et al. [3] also did not verify increase in soybean and maize yield, after plowing and disking a Loamy Oxisol, in no-till for 17 years.

In the soybean crop there was no interaction between soil management systems and soil layers and there was lower compaction in the $0-5 \mathrm{~cm}$ depth layer, through lower bulk density, higher porosity and macroporosity (2013/14 season-Table 1). However, soybean yield was higher in no-till with cover crops compared to tillage after winter fallow (2013/14 season Figure 8(a) and 2014/15 season Figure $8(\mathrm{~b})$ ), indicating a beneficial effect of cover crops and low no-till

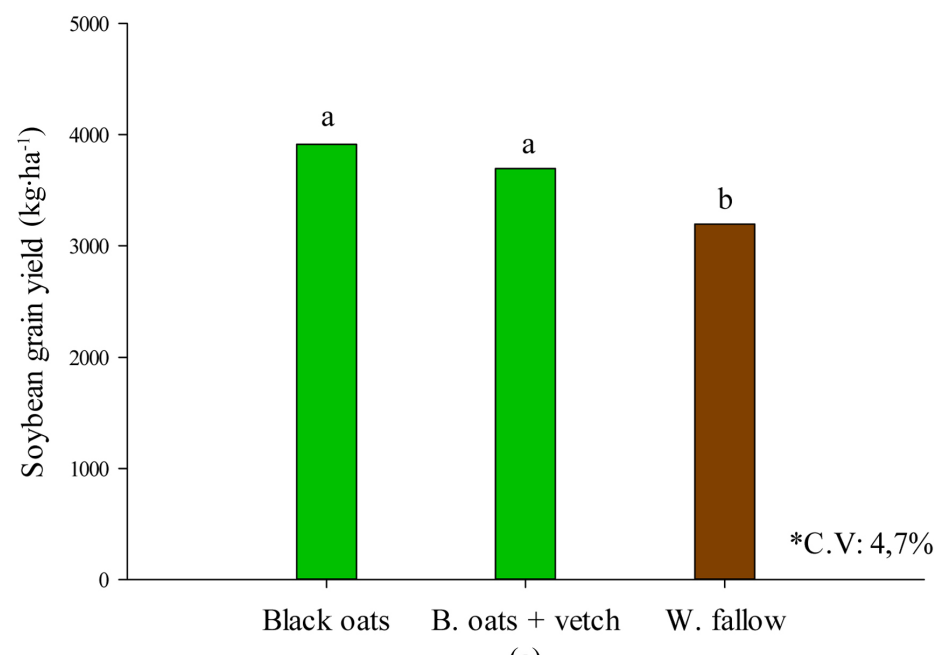

(a)

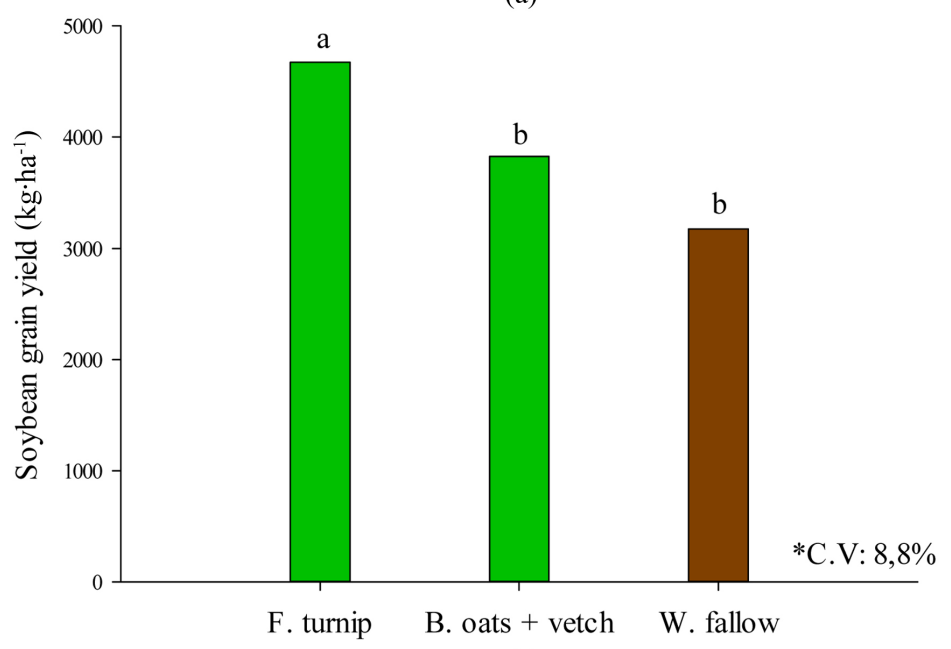

(b)

Figure 8. Grain yield of dry soybean (BMX Alvo 2013/14 season (a) and 2014/15 (b)), to soil management practices, crop rotation and cover crops. ${ }^{\star}$ Coefficient of variation. 
and tillage influence. In the literature, there are several studies comparing no-till and tillage and also indicate cover crops beneficial results. However, Klein and Camara [19] did not verify differences in soybean yield in no-till compared to tillage. In this context, it is necessary to consider the soil degree of compaction in no-till, which when excessive can reduce plant productivity [22], a fact that possibly explains the similar crop yields in no-till and tillage or, for the soybean crop, greater yield in no-till due to the cover crops benefits and low soil compaction.

In the second growing season (2014/15), the physical soil properties changed less between the treatments and layers and there was no interaction. For dry beans, the bulk density and the microporosity were smaller and the total porosity and macroporosity were higher in the fallow with conventional tillage. For maize and soybean, winter fallow also presented lower compaction, however, characterized by lower number of soil physical properties (Table 2).

Dry beans grain yield did not differ between no-till and tillage systems and cover crops (2014/15 season Figure 6(b)). For maize, the highest grain yield was obtained in no-till with vetch, as occurred in the first harvest, and the lowest was obtained in tillage with winter fallow (2014/15 season Figure 7(b)). The highest soybean yield was obtained in no-till after forage turnip and no-till with black oats + vetch did not differ from tillage after winter fallow (2014/15 season Figure $8(\mathrm{~b})$ ). These results allow to infer that tillage, despite showed lower compaction, evaluated by the soil physical properties, did not promote dry beans, maize and soybean greater grain yield. Suzuki et al. [26], found that the intermediate degree of compaction of Alfisols and Ultisol soils promotes higher soybean yield. So, no-tillage with cover crops and crop rotation inclusion is recommended because of the innumerable system advantages.

The preset scientific paper brings some combinations of cover crops used in the no-tillage system, therefore, it is important to point out that the study leads to a reality, characteristic of the adopted management practices. New studies with other cover crops species and soil management are presented as alternatives for future research in the area.

\section{Conclusions}

Crop rotation and cover crops under no-till system, most of the times, increase maize and soybean grain yields compared to winter fallow and without crop rotation.

The stabilized no-tillage system, with crop rotation, presents greater soil compaction in the superficial layer compared to the conventional tillage, but does not reduce dry beans, maize and soybean yields.

\section{Acknowledgements}

The third author thanks by the scholarship PQ/CNPq and the last by the scholarship DTI/FAPERGS/CAPES/UFFS. 


\section{References}

[1] USDA (2017) World Agricultural Production. Foreign Agricultural Service, Washington DC.

[2] Silva, S.G.C., Silva, Á.P., Giarola, N.F.B., Tormena, C.A. and Sá, J.C.M. (2012) Temporary Effect of Chiseling on the Compaction of a Rhodic Hapludox Under No-Tillage. Brazilian Journal of Soil Science, 36, 547-555. https://doi.org/10.1590/S0100-06832012000200024

[3] Fidalski, J., Yagi, R. and Tormena, C.A. (2015) Occasional Soil Turnover and Liming in a Clayey Oxisol under a Consolidated No-Tillage System. Brazilian Journal of Soil Science, 39, 1483-1489. [In Portuguese, with Abstract in English]

[4] Botta, G.F., Tolon-Becerra, A., Lastra-Bravo, S. and Tourn, M. (2010) Tillage and Traffic Effects (Planters and Tractors) on Soil Compaction and Soybean (Glycine max L.) Yields in Argentinean pampas. Soil \& Tillage Research, 110, 167-174. https://doi.org/10.1016/j.still.2010.07.001

[5] Gubiani, P.I., Reichert, J.M. and Reinert, D.J. (2014) Interaction between Water Availability and Soil Compaction on Common Bean Growth and Yield. Brazilian Journal of Soil Science, 38, 765-733. [In Portuguese, with Abstract in English].

[6] Nawaz, M.F., Bourrié, G. and Trolard, F. (2013) Soil Compaction Impact and Modelling. A Review. Agronomy for Sustainable Development, 33, 291-309.

https://doi.org/10.1007/s13593-011-0071-8

[7] Sivarajana, S., Maharlooeia, M., Bajwaa, S.G. and Nowatzki, J. (2018) Impact of Soil Compaction Due to Wheel Traffic on Corn and Soybean Growth, Development and Yield. Soil \& Tillage, 175, 234-243. https://doi.org/10.1016/j.still.2017.09.001

[8] Siczek, A. and Lipiec, J. (2011) Soybean Nodulation and Nitrogen Fixation in Response to Soil Compaction and Surface Straw Mulching. Soil \& Tillage Research, 114, 50-56. https://doi.org/10.1016/j.still.2011.04.001

[9] Reichert, J.M., Rosa, V.T., Vogelmann, E.S., Rosa, D.P., Horn, R., Reinert, D.J., Sattler, A. and Denardin, J.E. (2016) Conceptual Framework for Capacity and Intensity Physical Soil Properties Affected by Short and Long-Term (14 Years) Continuous No-Tillage and Controlled Traffic. Soil \& Tillage Research, 158, 123-136. https://doi.org/10.1016/j.still.2015.11.010

[10] Gubiani, P.I., Van Lier, Q.J., Drescher, M.S., Mezzomo, H.C. and Veiga, C.M.C. (2015) Relationship between Bulk Density and Water Content of an Oxisol Subjected to Repeated Cycles of Expansion and Contraction. Brazilian Journal of Soil Science, 39, 100-108. [In Portuguese, with Abstract in English]

[11] Tormena, C.A., Silva, Á.P. and Libardi, P.L. (1999) Soil Physical Quality of a Brazilian Oxisol under Two Tillage Systems Using the Least Limiting Water Range Approach. Soil \& Tillage Research, 52, 223-232.

https://doi.org/10.1016/S0167-1987(99)00086-0

[12] Lima, C.L.R., Miola, E.C.C., Timm, L.C., Pauletto, E.A. and Silva, Á.P. (2012) Soil Compressibility and Least Limiting Water Range of a Constructed Soil under Cover Crops after Coal Mining in Southern Brazil. Soil \& Tillage Research, 124, 190-195. https://doi.org/10.1016/j.still.2012.06.006

[13] Rosim, D.C., Maria, I.C., Silva, R. and Silva, Á.P. (2012) Soil Compaction in a Rhodic hapludox Soil as Influenced by Straw Management and Quantity on Surface. Bragantia, 71, 502-508. [In Portuguese, with Abstract in English] https://doi.org/10.1590/S0006-87052013005000003

[14] Peel, M.C., Finlayson, B.L. and Mcmahon, T.A. (2007) Updated World Map of the 
Köppen-Geiger Climate Classification. Hydrology and Earth System Sciences, 11, 1633-1644. https://doi.org/10.5194/hess-11-1633-2007

[15] Soil Survey Staff (2014) Keys to Soil Taxonomy. 12th Edition, USDA, Natural Resources Conservation Service, Washington DC.

[16] Claessen, M.E.C. (1997) Manual de métodos de análise de solo. 2nd Edition, Embrapa CNPS, Rio de Janeiro, $212 \mathrm{p}$.

[17] Loch, R.J. (2000) Effects of Vegetation Cover on Runoff and Erosion under Simulated Rain and Overland Flow on a Rehabilitated Site on the Meandu Mine, Tarong, Queensland. Australian Journal of Soil Research, 38, 299-312. https://doi.org/10.1071/SR99030

[18] Marcolan, A.L. and Anghinoni, I. (2006) Physical Attributes of an Ultisol and Crop Yield as Affected by Soil Mobilization in No-Tillage System. Brazilian Journal of Soil Science, 30, 163-170. (In Portuguese)

[19] Klein, V.A. and Camara, R.K. (2007) Soybean Grain Yield and Least Limiting Water Range in an Oxisol under Chiseled No-Tillage. Brazilian Journal of Soil Science, 31, 221-227. (In Portuguese)

[20] Boland, G.J. and Hall, R. (1994) Index of Plant Hosts of Sclerotinia sclerotiorum. Canadian Journal of Plant Pathology, 16, 93-108. https://doi.org/10.1080/07060669409500766

[21] Collares, G.L., Reinert, D.J., Reichert, J.M. and Kaiser, D.R. (2006) Soil Physical Quality on Black Beans Yield in an Alfisol. Pesquisa Agropecuária Brasileira, 41, 1663-1674. https://doi.org/10.1590/S0100-204X2006001100013

[22] Reichert, J.M., Suzuki, L.E.A.S., Reinert, D.J., Horn, R. and Håkansson, I. (2009) Reference Bulk Density and Critical Degree-of-Compactness for No-Till Crop Production in Subtropical Highly Weathered Soils. Soil \& Tillage Research, 102, 242-254. https://doi.org/10.1016/j.still.2008.07.002

[23] Balbinot Junior, A.A., Veiga, M., Moraes, A., Pelissari, A., Mafra, A.L. and Piccolla, C.D. (2011) Winter Pasture and Cover Crops and Their Effects on Soil and Summer Grain Crops. Pesquisa Agropecuária Brasileira, 46, 1357-1363. https://doi.org/10.1590/S0100-204X2011001000032

[24] Martins, R.M.G. and Rosa Junior, E.J. (2005) Preceding Cultures Conditioning Corn Crop Development and Soil Attributes in No Tillage System. Acta Scientiarum: Agronomy, 27, 225-232. (In Portuguese)

[25] Aita, C., Basso, C.J., Ceretta, C.A., Gonçalves, C.N. and Ros, C.O. (2001) Cover Crops as a Source of Nitrogen to Corn. Brazilian Journal of Soil Science, 25, 157-165. (In Portuguese)

[26] Suzuki, L.E.A.S., Reichert, J.M. and Reinert, D.J. (2013) Degree of Compactness, Soil Physical Properties and Yield of Soybean in Six Soils under No-Tillage. Soil Research, 51, 311-321. https://doi.org/10.1071/SR12306 